\title{
PRICE CONTROL IN WAR AND EMERGENCY
}

\author{
Jules Abels $\dagger$ \\ The Problem-Regulation or Requisition?
}

Since Nebbia v. New York in I934, ${ }^{1}$ the Supreme Court has regarded price fixing with beneficent approval where it was duly demonstrated that economic circumstances necessitated so drastic an expedient, either under the police power of the State, ${ }^{2}$ or the Interstate Commerce Clause of the Federal Constitution. ${ }^{3} A$ fortiori, it may be assumed that in the due exercise of the war power, ${ }^{4}$ price fixing legislation reasonably calculated to preserve the domestic economy from dislocation by control of the price structure will be sustained by the present Court. ${ }^{5}$

The basic problem presented by war-time price control involves the constitutional necessity of awarding just compensation, either for the product whose price is fixed, or, on the other hand, a "fair return on fair value" for the business placed, under the price fixing yoke. Stated in another way-are the prices as fixed by the legislative mandate reviewable as to reasonableness by the courts, as in all familiar instances of public utility regulation and direct governmental appropriation by eminent domain?

To analyze the specific problem of war-time control, it is essential to review the judicial history of price fixing to determine its basic nature, whether a species of regulation or requisition.

† A. B., 1934, College of the City of New York; LL. B., I937, Columbia University; M. P.A., 194r, Harvard University; member of the New York Bar; Price Control Editor, Research Institute of America, Inc.

I. 29I U. S. 502 (1934).

2. Mayo v. Lakeland Highlands Canning Co., Inc., 309 U. S. 3 IO (I940) ; Milk Control Board v. Eisenberg Farm Products, 306 U. S. 346 (1939); Townsend v. Yeomans, 30I U. S. 44I (1937) ; Borden's Co. v. Ten Eyck, 297 U. S. 251 (I936) ; Hegeman Farms Corp. v. Baldwin, 293 U. S. I63 (I934).

3. Sunshine Anthracite Coal Co. v. Adkins, 310 U. S. 38I (I940); United States v. Rock Royal Co-operative, Inc., 307 U. S. 533 (r939) ; H. P. Hood \& Sons, Inc. v. United States, 307 U. S. 588 (1939). For a general discussion of Federal price fixing since Nebbia $v$. New York, see Polikoff, Comnnodity Price Fixing and the Supreme Court (1940) 88 U. OF PA. L. REV. 934.

4. For a discussion of war power, see Black, The Theory of the War Power Under the Constitution (1926) 60 AM. L. REv. 3r. See Miller v. United States, II Wall. 268, 305 (U. S. 1870) ; United States v. McIntosh, 283 U. S. 605, 622, 623 (I93I). See also note 63 infra.

5. A full discussion of price-fixing constitutionality is contained in a brief submitted by David Ginsburg, General Counsel of OPA. Hearings Before Committee on Banking and Currency on H. R. 5479, 77th Cong., Ist Sess. (194I) 310. See also Note, American Economic Mobilization (I942) 55 HARv. L. REv. 427, 477, and Hannah, Some Aspects of Price Control in War-Time (194I) 27 CoRN. L. Q. 2I, for discussions of war-time price control. 


\section{The Theory-Fitring into the Regulation Concept}

Regulation is the exercise of either the police power of the state or one of the delegated powers residing in the Federal Government; requisition is the exercise of a power inherent in sovereignty, and the reliance upon express power is unnecessary.

It has long been established that regulation does not require compensation on the part of the sovereign for damage done, though the sovereign may, as a matter of choice, award compensation for injury sustained incident to obedience to its decree. ${ }^{6}$ On the other hand, just compensation is an absolute constitutional restraint on the exercise of the requisitioning power. It is obvious that any restriction on property insofar as it inflicts damage or diminishes the returns from property is pro tanto a taking of the property. ${ }^{7}$ Thus viewed from the standpoint of the individual, regulation and taking, though supposedly different in kind, are only different in degree. This problem as to how far substantial damage can be inflicted in the exercise of the regulatory power without compensation is one that has disturbed judicial thought. Mr. Justice Holmes in Pennsylvania Coal Co. v. Mahon ${ }^{8}$ in I922, extending a line of thought expressed in Block $v$. Hirsch ${ }^{9}$ in the previous year, stated that when the damage "reaches a certain magnitude, in most if not in all cases there must be an exercise of eminent domain and compensation to sustain the act."

Where real property has been injured or destroyed, the magnitude of the loss, the Mahon test, may guide the court in determining whether a taking has occurred. As to the bulk of regulations which impinge on the unmolested conduct of business and hence result in a diminution of earning power, a direct appropriation to public use cannot be found and the eminent domain principle is difficult to apply. Since the government's liability in requisition is based on implied contract, an injury or destruction of property without appropriation cannot ground a claim for reimbursement. ${ }^{10}$

6. "It has long been settled law that the imposing of uncompensated charges, involved in obeying a law, passed in a reasonable exercise of the police power, is not a taking of property without due process of law, within the meaning of the Fourteenth Amendment to the Constitution of the United States." Northwestern Pac. Ry. v. Puget Sound Ry., 250 U. S. 332, 336 (Igrg). Freund stresses the point in Eminent Domain (1935) III ENCYC. Soc. SCIENCES 493.

7. Abbot, The Police Power and the Right to Compensation (1889) 3 Harv. L. REV. 189 , I9I.

8. 260 U. S. 393,413 (I922).

9. 256 U. S. 135, I55 (I921).

Io. Note cases of the last war disclaiming governmental liability for consequential damages: U. S. Bedding Co. v. United States, 266 U. S. $49 \mathrm{I}$ (I925); Campbell v. United States, 266 U. S. 368 (Ig24) ; Omnia Co. v. United States, 26r U. S. 502 (1923) ; Luckenbach S. S. Co. v. United States, 42 F. (2d) I56 (1930). See Cormack, Legal Concepts in Cases of Eminent Domain (I93I) $4 \mathrm{I}$ Y YLE L. J. $22 \mathrm{I}$. 
Regulation is aimed to produce or restrain action by the individual -in contrast to requisition, the damage done is an ulterior result, but not the immediate motive. In regulation, violation with punishment or obedience with immunity hinges on the volition of the individual. Requisition, however, is unilateral in the sense that it is executed by a paramount power regardless of the individual will.

As an outgrowth of its volitional rather than compulsive character, the regulation is laid upon the whole community, or in another aspect, on a class of persons in the community, while the requisition is applied separately to the individual owners.

Judged by these outward criteria, it is apparent that war-time price fixing bears on its face the indicia of a regulation rather than a requisition. (I) The exercise of power is predicated on a delegated rather than an inherent power, price fixing being designed as an implement to the war power to promote the proper conduct of the war. (2) No direct appropriation or enrichment results to the Government from transactions between individuals. (3) The individual is afforded the option to obey or defy; in this case, he may refrain from sale altogether. (4) The sovereign command is applied not to individuals but embraces the community as a whole.

\section{The Evolution-Towards the Regulation Concept}

Price fixing evolved in the field of public utility regulation wherein a modified form of eminent domain thinking has become deeply rooted in the "fair return on fair value" doctrine. Originally, however, in Munn v. Illinois in $1876,{ }^{11}$ when the Court gave birth to the theory of "affectation with the public interest" to sustain the fixing of prices charged by grain elevators for storage (the extant interpretation of the scope of the police power being deemed inadequate for the purpose), price fixing was conceived of as a regulation rather than a requisition. In reply to the argument that though the right to regulate might exist, yet the rates were subject to the duty to give just compensation, the Court said that "for protection against abuses by legislatures the people must resort to the polls, not to the courts." 12 It is a logical consequence of the regulatory principle that the amount of the rate fixed is in the legislative discretion as one of the means adopted to accomplish its purpose.

The dissent bore within it, however, the seeds of the later doctrine. Mr. Justice Field contended that though many regulations inter-

Ir. 94 U. S. Ir3 (1876).

12. Id. at I34. "In his (Waite's) thought the phrase is still a generic term of common law, on all fours with 'public morals', 'public safety', and 'public health'." Hamilton, Affectation With Public Interest (1930) 39 Y ALE L. J. 1089, 1096. 
fere with the use of property, they do not interfere with the compensation to be demanded for that property. He inferred that an owner has two distinct rights as to his property. The first is one in rem, and valid regulations pertain only to that use; the second is that of absolute protection as against all non-owners. Price regulation as a drastic interference with that title and possession is, in all instances, the equivalent of a taking or expropriation.

Such was the thrust of the decision in Smyth v. Ames, ${ }^{13}$ which launched the Court on its weird quest for the "fair return on fair value" formula. When the state assumes the right of regulation of utility rates, the fair return which it allows is, in fact, the just compensation required in condemnation proceedings. ${ }^{14}$ The Government permits the stockholders to operate the utility, but limits them to a reasonable return equal to the fair rental of the perpetual leasehold on the property.

If the "regulation" of public utilities were, technically speaking, a regulation in the exercise of the police power, then no compensation would be required. Thus, encompassing public utility regulation under the "just compensation" rubric is a necessary choice. However, it is not identical with a taking, but rather is a substantial analogy thereto, since public utility regulation envisages a change in the value of the going concern, while condemnation requires an exact quid pro quo, which obviously would render futile any attempt to remedy the economic maladjustment at which the regulation is aimed.

Having sustained price fixing in the case of utilities "affected with the public interest," the court reversed the syllogism "by the fallacy of misplaced concreteness", converting it into the proposition that only where the business was so "affected" was price fixing constitutional, the majority deducing from an a priori formulation of the nature of a public utility. ${ }^{15}$ This viewpoint is explicable on the ground that the limitation imposed was not on the police power but on the scope of the "public use" in the exertion of eminent domain, businesses such as employment agencies or theater ticket brokerage services not falling within that category. ${ }^{16}$

13. I69 U. S. 466 (1898), discussed by Hale, The "Fair Value" Merry-Go-Round (1939) 33 IrL. L. REv. 517.

I4. This was stated explicitly by Roberts, J., in West v. Telephone Co., 295 U. S. 662 (1935) at 67I.

I 5. Williams v. Standard Oil Co., 278 U. S. 235 (I929); Ribnik v. McBride, 277 U. S. 350 (1928); Tyson \& Bros. v. Banton, 273 U. S. 418 (I927). Related cases are New State Ice Co. v. Liebmann, 285 U. S. 262 (I932) and Wolff Packing Co. v. Ind. Relations Court, 262 U. S. 522 (I923).

I6. There are expressions in the minority opinions impugning the validity of "affectation with the public interest" as a distinct category. Thus, see Brandeis, J., in the Liebmonn case (p. 302), "The notion of a distinct category of business 'affected with a public interest', employing property 'devoted to a public use', rests upon historical error. . . In my opinion, the true principle is that the State's power extends 
During this period, however, the Court was constrained to recognize the inexpediency of following the doctrine consistently. Thus, though insurance companies were placed within the orbit of the rule, the Court in Aetna Insurance Co. v. Hyde ${ }^{17}$ stated that it was unnecessary that aggregate collections of premiums fixed as to amount by the state yield a reasonable profit to all companies engaged in the business. Similarly, Tagg Bros. \& Moorhead v. United States ${ }^{18}$ tends to support the conclusion that uniform rates imposed on an entire industry would be sustained if compensatory to a reasonable number. A ready rationalization is offered by the sound principle, unfortunately not too fully explored, that an inefficient public utility is not entitled to a return equal to that of its more efficient brother.

With Nebbia v. New York, price fixing voyaged on new seas. The depression revealing itself in a malady of prices, the effort of price adjustment has gone beyond the immediate raising or lowering of price to the control of the price structure in order to prevent an evil of great harm to the public, the purpose conforming to the accepted notion of the use of the police power. The predominant tone of the Nebbia decision is one stressing the intimate connection between the disrupted price structure and the moribund state of an industry engaged in the distribution of a commodity indispensable for public health. Similarly, in Sunshine Anthracite Coal Co. v. Adkins ${ }^{19}$ in r940, upholding the Bituminous Coal Act of I937, the Court dwelt on the dislocations of a vital national industry, and the concomitant evils resulting from an uncontrolled price structure.

The validation of minimum price fixing per se did not raise the issue of just compensation, since a floor is thereby set under cut-throat competition, the state's action being comparable to that made by the members of an industry for their own benefit. However, the issue was specifically litigated in Hegeman Corp. $v$. Baldwin, ${ }^{20}$ wherein it was claimed that the differential between the minimum price to be paid to the producer for milk, and the price determined by competition was confiscatory as inadequate to cover operating expenses. To

to every regulation of any business reasonably required and appropriate for the public protection." However, this should be understood as referring to the substantive right of regulation, not to the correspondent incidents of the powers. Thus, see Holmes, J., in the Tyson case ( $p_{i} 446$ ), "The truth seems to me to be that, subject to compensation when compensation is dne, the legislature may forbid or restrict any business when it has a sufficient force of public opinion behind it." (Italics supplied.)

17. 275 U. S. 440,447 (1928). The Court had previously held that insurance companies are "affected with the public interest". German Alliance Co. v. Kansas, 233 U. S. 389 (I914).

I8. 280 U. S. 420 (I930). Rates for stockyards services upheld, though confiscatory as to some of the plaintiffs. Cf. Acker v. United States, 298 U. S. 426 (I936).

19. 310 U. S. 38I (1940).

20. 293 U. S. 163 (I934). 
this objection, Cardozo gave short shrift, succinctly distinguishing the case from that of a public utility.

"Much is made of a supposed analogy between the plight in which the appellant finds itself, and that of public utilities subjected to maximum rates that do not yield a fair return. But the analogy, when scrutinized, is seen to be unreal. A public utility in such circumstances has no outlet of escape. If it is running its business with reasonable economy, it must break the law or bleed to death. But that is not the alternative offered when the law prescribes a minimum. An outlet is then available to the regulated business, an outlet that presumably will be utilized whenever use becomes expedient. If the price is not raised, the reason must be that efficient operators find that they can get along without a change. Either that must be so, or else, as was pointed out in the opinion below, the industry will perish." 21

The adoption of the theory of regulation was even more explicitly stated in the lower court decision by Learned Hand, ${ }^{22}$ who demonstrated that price fixing no more impairs the ownership and disposition of property than a myriad of regulations affecting use.

Maximum price fixing in a competitive industry in which there is a disparity in operating expenses immediately raises the serious problem of the means of guaranteeing a fair return to all its members. Just compensation to the less efficient firms results in an exorbitant return to the more efficient-just compensation to the more efficient results in a confiscatory return to the less efficient. In the Adkins case, in which maximum as well as minimum prices were upheld, the issue of just compensation was met by the administrative rule of price fixing under which the Bituminous Coal Commission is charged to act. This rule is designed to guarantee each mine a fair return on the fair value of its property. The elaborate administrative mechanism was alluded to by the Court relative only to the definitiveness of the administrative standard in the delegation of legislative power. The Court did not indicate that such a method was required as a substantive adjunct to price fixing.

2I. Id. at I7I.

22. 6 F. Supp. 297,298 (S. D. N. Y. 1934). "All sorts of regulations may affect the price of materials or machinery necessary to another industry. The elimination of fire hazards may require high rents; they may not be attainable. The observance of sanitary regulations in factories may be expensive; more than the market will bear. Conformity with prescribed standards of quality and packing may turn a living profit into a loss. . . If the plaintiff be right, in every case the validity of the regulation would depend upon whether the addition to the cost resulted in the elimination of some of the producers. Legislation could scarcely go on at all if its indirect results, its final incidence, must be so nicely adjusted. . The 'Police Power' was sometimes spoken of as though it concerned only 'health and safety'. That mode has disappeared; the purpose of the State of New York to preserve its dairy industry may involve remote repercussions as mortal to some individuals as its purpose to abolish sweatshops; but once it be agreed that the state may, interpose for either end in the "free play of supply and demand', the incidents follow." 
The perpetuation of the concept of requisition with price control is one that is not longer supportable on the ground of the distinction between use and disposition of property. Regulations as to use affect final price; the existence of a multitude of regulations directly impinging on freedom of disposition of property is unquestioned.

In public utilities the "taking" concept is so deeply imbedded that it cannot be dislodged. But ascribing legal homogeneity to all efforts at price control seems to be unfounded. The nature of such control is multiform. There is a clear difference between control in which the effort is directed only at lowering price, and control which is aimed at the larger repercussions to the economy resulting from distorted prices. The latter is properly within the legitimate scope of the police power, the former, perhaps, may be justified only when the business is "affected with the public interest." 23 The differentiation of a public utility from an ordinary business was underscored by Cardozo in the Hegeman case on an additional ground-in the case of the non-utility there is always the option to withdraw to avoid the loss occasioned by the legislative act (the usual attribute of the regulation). The rate set by the legislature is a matter of "statecraft"; the sole limitation, he implies, is that the law must not have the ultimate effect of destruction of the industry as a whole. Such is the frontier of the arbitrary and unreasonable.

Attention must be directed to the larger purpose that price fixing has in mind, with price fixing as merely the device to achieve that end. War-time price control, focusing on its purpose and effect, rather than outward form, is intimately connected with those ends toward which the police power (or war power) is properly exerted.

\section{Without Statute-A Requisition Medium}

To facilitate an analysis of war-time price fixing from the standpoint of regulation and requisition, it is desirable to make two logical divisions of the subject matter. In the first stage of control, the government is involved as a huge purchaser from private industry; in the second stage, the government, to protect the civilian population from exploitation, regulates the prices of civilian commodities previously unregulated as to price.

In the first step on which the government embarks, the assumption of the role of a gigantic entrepreneur, the government's legal relationship with industry is constructed on the foundation of a requisi-

23. Note that after the Nebbia case, state courts continued to hold statutes unconstitutional on the ground that the businesses were not "affected with the public interest." See Mobile v. Rouse, 233 Ala. 622, 173 So. 266 (1937) ; Becker v. State, 37 Del. 454, I85 Atl. 92 (I936); Duncan v. Des Moines, 222 Iowa 218, 268 N. W. 547 (I936). 
tion, rather than a regulation. Section 9 of the Burke-Wadsworth Act, ${ }^{24}$ substantially similar to the National Defense Act of I9I6, is a commandeering statute. The positive control exercised by the government rests on three functions, commandeering, priority, and price fixing. It is erroneous to regard these as disjoined-on the contrary, priority is merely the reverse side of the price fixing coin, and price fixing is an outgrowth of the power to commandeer and administer priorities.

Priority is the widest and most important of the war-time controls. It introduces a scheme powerful in its effects for maximizing production, and synchronizing production and deliveries for war use. It is also one of the strongest weapons in the hands of the government for enforcing its industrial control measures.

In the view of the essentiality of the control, it is important to understand its legal nature. Priority is a Janus-Headed device. There is the priority of industry vis-a-vis the government, and there is the priority of industry vis-a-vis its subcontractors. Facing the government, the industry is confronted with a duty-facing its subcontractors, it is endowed with a right. Strictly speaking, under existing law, priority is the corollary of the requisition since, if the government takes by eminent domain, whether in fiction or fact, it is obviously entitled to be served first. Thus the present express statutory grant of government priority is mere redundancy. There were suits in the courts for breach of contract by private contractors against industries which, because of subsequent contractual liability to the government, were unable to fulfill their contracts. The defense of impossibility of performance was sustained in Roxford Kuitting Co. v. Moore \& Tierney, Inc. ${ }^{25}$ and Mawhinney $v$. Milbrook Mills, ${ }^{26}$ the courts recognizing the coercive nature of the contracts, whether or not voluntarily solicited, thus sanctioning priority in connection with a government contract, since a taking is implied.

Secondary priority is of a different content, however. It is the more important since in addition to canalizing production throughout the economy beyond the primary contractor, it is the inducement to contract with the government in return for the vital privilege of obtain-

24. 54 STAt. 885 (1940), 50 U. S. C. A. § 309 (Supp. I941).

25. 265 Fed. I77 (C. C. A. 2 d, 1920).

26. 23I N. Y. 290, I32 N. E. 93 (r92I). Note the Court's statement at 300 (132 N. E. at 96). "The one who gave his service with alacrity under such conditions should at least be considered with as much favor as he who held back until threatened or his property commandeered. The laggard who feared the financial results under his civilian contracts merits no encouragement. The fact that the defendant may have sought or welcomed the government work is immaterial. The fact is the government gave it orders which had to be filled at once. The Act of Congress, the necessity of the times, brooked no delay." Cf. American Smelting \& Refining Co. v. United States, 259 U. S. 75 (1922). See also Brown, The Effect of Conscription of Industry on Contracts for the Sale of Goods (I942) 90 U. of PA. L. REv. 533. 
ing necessary materials. Herein there is no privity between the government and its subcontractors, the choice of whom has been made by the contractor. The government sanctions a devolution of authority on the contractor whose selectees are automatically endowed with priority. Where a party to a contract was unable to obtain materials due to lack of priority, a defense of impossibility of performance was held defective, and this decision seems doctrinally correct, since there was no government taking. ${ }^{27}$ Similarly, a subcontractor who is unable to perform because he is supplying a government contractor, would probably not be excused from performance on the ground of a taking. The legal authority to enforce priority orders must therefore rest on a different basis. The government during the last war had taken possession of the railroad system and had asserted dominion over the fuel supply. It thus based its power to dictate policy for the entire economy on its ability to cut off non-conformers from transportation and fuel.

While the authority of the War Industries Board to administer priorities was partial, being coordinate to the requisition, its authority to fix prices was non-existent. In a narrow sense, the Board did not fix prices, since the prices were agreed on by the members of the industry after consultation with the Price Fixing Committee. Ostensibly the agreements were voluntary - in fact, they were executed under veiled coercion, the threat of commandeering, or later the more effective threat, the denial of the coveted priority. The shift of emphasis from the universal spirit of cooperation stressed in the Baruch report of I92I to his blunt admission of the use of duress in his testimony in I93 I is striking. At the latter time he admitted that universal compliance was obtainable only with the aid of potential compulsion, and that "price fixing by agreement" was a euphemism on the same plane as referring to registrants for the draft as "Mass Volunteers". ${ }^{28}$

The formula which the government employed to induce price agreements was as follows:

"These are the prices to which the government will agree; if you are willing to enter into a voluntary arrangement with us, you will be paid these prices for your goods, but if you refuse to do so, we will be compelled to ask the properly constituted authorities to commandeer your output or your plant and give you just compensation therefor as provided by statute." 29

27. Town of North Hempstead v. Public Service Corp., I07 Misc. I9, I76 N. Y. Supp. 621 (Sup. Ct. Igrg), aff'd mem., I92 App. Div. 924, Igo N. Y. Supp. 955 (2d Dep't, Ig2r); Crown Embroidery Works v. Gordon, I90 App. Div. 472, I80 NN. Y. Supp. I58 (Ist Dep't, I920), aff'd mem., I96 App. Div. 937, I87 N. Y. Supp. 932 (Ist Dep't, rg2r).

28. Hearings Before War Policies Commission on $H$. J. Res. 25I, 7Ist Cong., ad Sess. (I93I) 8I7. For the legal effect of the agreement, see Cardozo, J., in Standard Chemicals v. Waugh, 23I N. Y. 5I, 58, 13I N. E. 566, 568 (I92I).

29. Garrett, Government Control Over Prices (Ig20) 235. 
The legal section of the Board on June II, I9I8, concluded that a threat to commandeer expressed in this form to induce the fixing of price did not constitute duress. ${ }^{30}$ At a later time, with the smooth functioning of secondary priority, a threat to choke an industry by withholding vital supplies supplanted commandeering as the more potent threat.

Prior to the present statute, price orders of the Office of Price Administration (hereinafter referred to as OPA) were admittedly enforced by threats. All schedules stated that offenders would be exposed to public censure, and would be boycotted by procurement officials. Additionally, the government could requisition at will, and use the priorities and allocations machinery to punish recalcitrants.

It is thus evident that the common matrix of the three weapons of control exercised by the government in the absence of a price control law is the concept of requisition. Generated out of conscription thinking, the "Draft Industry" Amendment congrues with the popular feeling that the burdens of war should be "equalized" as between property and human beings. The proponents of such a course, by mistaken analogy with the conscription of manpower, have been led to emphasize the use and implementation of the requisition as a method of control.

However, in studying the purport and operation of the BurkeWadsworth Act more closely, it appears that the government is needlessly encumbering itself by proclaiming the use of the device of requisition where the effect may be most expeditiously attained by regulation, and where, in fact, the compulsion may carry all the external characteristics of a regulation. The Act is burdened with an inherent logical inconsistency arising out of the reliance on the requisition; it operates detrimentally to restrict governmental authority; in addition, the legality of price fixing attained by the indirect approach rests on uncertain ground.

\section{InCONSISTENCY IN THE BURKE-WADSWORTH ACT}

In considering the structure of the Burke-Wadsworth Act we should note that it contemplates two takings. The government is vested with the power to place orders with any concern for such products or materials as are required and are being produced by that firm, and grants the power to determine reasonable and just prices for that

30. It is true that at common law a threat to do what one had a legal right to do did not constitute duress. There is a plethora of authority, however, for the modern rule that duress is a question of fact to be determined in each case, and the character of the threat is relevant only in determining whether the state of mind was induced by the threat employed. Where parties to a contract are not bargaining at arm's length, but on unequal terms, arising out of a position to dictate due to the public or institutional character of one of the parties, a finding of duress may be readily made, despite the legality of the threat. 
product. Such an order is considered a "compulsory order" or a "commandeering of the output" of that firm; the price fixed by the executive agency is the measure of "just compensation" adopted, reviewable by the courts. However, if the industry withholds acquiescence, then another commandeering may occur-that of the plant itself. The question inevitably presents itself-if the government in the first case is taking by eminent domain, how can the lack of consent of the owner interpose any obstacle, since it is of the very essence of eminent domain that the property is taken from its owner volens nolens? 31

The answer, to be sure, is that there is no res in existence to take, since the product is only in potens, and will be available for requisition only if the owner chooses to comply with the government order. Thus the compulsion to produce, if enforceable in all instances, would be tantamount to involuntary servitude. This question apparently vexed H. M. Channing, Chief of the Legal Section of the War Industries Board, since he wrote in a memorandum to the Board:

"With relation to compulsory orders for production of ordinary staple commodities, as we construe the statutes, there is contemplated a taking of the finished commodity rather than an order for involuntary performance of service. The language used in the statutes, and the clearer constitutionality which would result from the first construction, tend to bring us to our conclusions, although there might be commandeer orders which would approach very closely orders for the performance of services." 32

Unfortunately, there is a temporal hiatus between the commandeering of the output and the existence of the finished product. Channing omits the reasoning which led him to his conclusion. It is difficult to see how an effective "commandeering", which by definition would deprive the individual of the option not to perform in every case, could be anything short of involuntary.

However, in practice, the individual does have that option. Pursuing the analysis further, if the taking of the product does not occur (due to the unwillingness of the owner, a complete inversion of the eminent domain theory), then the owner may be fined or his property commandeered. He is fined on the theory that he has violated a law which called for a positive act; but this is incompatible with the principle of the requisitioning of the product, since, as we have seen, Channing conceded that if the statute looked to positive action to be performed under all circumstances, it would amount to involuntary

31. Benedict v. United States, 27r Fed. 714, 7I9 (E. D. N. Y. I920). "A requisition is a one-sided exercise of authority."

32. Garrett, Governament Control Over Prices (ig20) 397. 
servitude. Moreover, the requisition does not call for any act on the part of the individual.

On the other hand, the property may be commandeered and a reasonable compensation paid for the rental. That this rental will be most generous is indicated by Prince Line $v$. United States ${ }^{33}$ wherein the Court directed that the fair rental should be based on the war profits made by the government in the use of the property. If the fair rental is to be an exact equivalent, or a quid pro quo, then the deterrent implicit in commandeering vanishes. However, the provision may operate as a penalty in fact because of the fear of offending public opinion in defying the government, and what Robert Brookings, the World War I Price Chief, quite acutely saw as a hesitancy on the part of industry to rely on the courts to award just compensation equivalent to lucrative war profits. Moreover, to regard government operation as intended to be a substitute for private operation rather than as a deterrent is to misapprehend the actualities of the situation.

Thus the penalty provisions of the Act are based on contradictory assumptions-namely, that the industry has failed to comply with what must be deemed a regulation (in view of the option retained by the individual) and hence is subjected to a penalty, or that a taking of the product having failed, a talking of the plant is resorted to. Logically, if the industry has failed to abide by a regulation, then the taking of the plant, as well as the fine, should be regarded as a penalty, and hence non-compensable. At both points of time the true meaning of the statute points to a regulation. Since the industry has in fact the option to decline the government's order, or even to withdraw from the industry, its consent can hardly be called a requisition. The consequences that follow such a refusal even as to the taking of the plant are intended to act as a penalty to deter such refusal. ${ }^{34}$

\section{Restrictive Effect of the Act}

We have seen previously that one edge of the Damocles sword, suspended over the head of manufacturers, was the threat to commandeer their output. The effect of such a threat is that the manufacturer will be compelled to deal with the government. But the compulsory order, since it is a requisition, entitles the owner to full market

33. 283 Fed. 535 (E. D. N. Y. I922), writ of error dismissed, 263 U. S. 727 (I923). See also Gershon Bros. Co. v. United States, 284 Fed. 849 (C. C. A. 5th, I922).

34. In Liggett \& Myers v. United States, 274 U. S. 215 (1927), the facts clearly denoted a compulsory order, and the Court so held. Attorney-General Mitchell, however, disputed such a finding contending that there was no requisition, since under the theory of eminent domain, the United States must "come and take it", whereas the production of goods under a contract manifests a willingness to comply with the order, the taking is contingent on this volition, and thus the fundamental premise of eminent domain has been banished. 
value, and thus makes obstructionism sound business policy in dealing with the government, in order to compel the issuance of the compulsory order. That prevailing market price would be the measure of recovery was conceded by Channing in a memorandum to the Board.

The opportunity to recover just compensation or market value is overtly contingent on the refusal of the manufacturer to enter into a voluntary agreement which would foreclose him from subsequent litigation. Thus in American Smelting Co. v. United States, ${ }^{35}$ a seller of copper to the government claimed that, though the language of contract had been used, since factually the threat of compulsion was imminent in the statute, it had in fact yielded to duress. The argument was dismissed by the Supreme Court in these words:

"It may be true that the claimant was yielding to the statute in a general way, and did not discriminate between what it was required to yield, and what it could reserve. But if it had desired to stand upon its legal rights, it should have saved the question of the price. It did not do so, but on the contrary so far as appears was willing to contract and was content in the main with what was offered." 36

The rationale implies a demarcation between a voluntary contract and a compulsory order, the logic of which seems to be untenable. Without adopting a Benthamite extreme, it is mere artifice to impute universal volition, manifested, allegedly, by submission without complaint, in the presence of potential compulsion. The manufacturer is confronted with a Hobson's choice-since it is certain that if the voluntary negotiations fail the requisition will issue, the ambiguity of mind of the manufacturer as to whether he is complying with a requisition, or voluntarily supplying the product is quite comprehensible. To force an election where the transition from a contract to a requisition is a mere matter of words is to erect a fictitious partition where none exists in fact. The reasoning, at odds with that in the Marwhinney case, in practice discourages cooperation, since the contractor, to preserve his right to sue, and moreover to protect himself against suits by civilian obligees, will prefer that the requisition issue. And yet, had the Court decided otherwise in the American Smelting Co. case, the courts would have been swamped with litigation, and it is arguable that all attempts to secure voluntary agreement or to get a price lower than prevailing market value would have been nullified by the judicial inference of compulsion in all government contracts.

Baruch attributed the circuitous method of price fixing adopted by the Board to the constitutional nemesis of "just compensation." 37

35. 259 U. S. 75 (I922).

36. Id. at 78 .

37. Baruch, Report of tHe War INDUStries BoARd (Ig2I) $75,76$. 
If the government engages in a bono fide taking, it is bound to pay market value. Price fixing is thus rendered nugatory, unless the transaction is successfully disguised as a voluntary offer by the industry to furnish the government with a product at a price below the prevailing one on the market.

A further consequence was pointed out to the War Policies Commission by Attorney-General Mitchell in a discussion of the Baruch Plan, envisaging total price control. ${ }^{38}$ Mitchell separated out the two areas of control-as to fixing of prices in the private markets, Mitchell contended that no opinion could be asserted in advance of the emergency, the latitude of power depending on the factual economic basis then present. However, as to the fixing of prices of products bought by the government, Mitchell argued that Congress could not constitutionally directly control the prices of products bought by the government, since, if the owner is dissatisfied with the price offered by the government, he is entitled to have just compensation ascertained and fixed by the courts. Thus stabilization would be illegal, in the matter of government prices. If, however, the two fields of civilian and government prices were thus divorced, the result would be such chaos as to make the plan unworkable. The government purchases goods in varying quantities. Must the prices be left uncontrolled, since the government may purchase a pound here, or a bushel there? Where can the line be drawn?

The position is fundamentally correct, unless the effect of the Gold Cases ${ }^{39}$ has modified the doctrine. Insofar as the government is taking by eminent domain, its liability is measurable by market value, and it seems to be morally bound to leave that market value unimpaired. Logical consistency can only be achieved by the replacement of the requisitioning by the regulatory principle-in the case of government purchases.

\section{Illegality of Indirect Price Control}

It remains to consider the insufficiency of the present statutory authority in respect to "voluntary" price agreements obtained through the latent threat of commandeering or withholding of priority. As a practical matter, it is debatable how far it is possible to bludgeon an industry which is conscious of its indispensability for industrial needs. In addition, however, the efficacy of this method is questionable from a legal viewpoint. How far can such agreements be sustained against

38. Hearings Before House Military Affairs Committee on $H . R .3$ and $H . R$. 5293, 74th Cong., Ist Sess. (I935) 734. 240.

39. Norman v. B. \& O. R. R., 294 U. S. 240 (1935) and cases in footnote, $i d$. at 
an affirmative showing of duress, particularly where the use of that duress is a matter of notoriety as to the last war and the present emergency? Conceding that a compulsory order is one entered into under duress, we have seen that the question may be one of fact-did the parties believe and understand that a compulsory order was being resorted to by the government? However, the issue may arise in a different fashion, with a claim by a contractor that though the contract in form had been voluntary, yet his consent had been secured by duress, other than the statutory compulsion.

Conceivably the court might dismiss the claim on the ground that a valid election had been made. However, if the circumstances were scrutinized with care, the basis for an opposite conclusion could well be found. The distinction between legality and illegality in the government's threat to commandeer the plant is a tenuous one, turning on subjective intent. Undoubtedly, if the industry is unwilling to furnish supplies to the government on what the latter deems equitable terms, the statute gives the government the right to intervene, commandeer the plant and operate it to supply its needs. To the extent, however, that its statement does not mirror factual intention, but is employed as a weapon to coerce, with prevision of that result, there can be little escape from the conclusion of duress. Since it is a matter of common knowledge that a large-scale appropriation of private industry is unfeasible in time of emergency, the basis of a finding of duress is apparent.

It is true that the government, like a private customer, has the privilege to grant or deny an order on what terms it pleases, but the vice of the situation lies in the fact that arms-length bargaining is absent, since the government has more cards in its hands than does the private customer. Thus, through priorities, it can virtually force acceptance on its own terms-the choice, in a real sense, is between the "rock and the whirlpool".40 Though the government has active control over the railroads, and potential control over the fuel supply, it is difficult to support the legality of price fixing and the regulation of priorities, predicated ostensibly on voluntary agreements, but based in reality on the threat to exert powers growing out of its strategic position. It should be noted in the case of secondary priority that it is administered without relation to the need for transportation, denial of transportation being employed unconcealedly as the effective threat. Apart from the important role played by public opinion in time of

40. Frost Trucking Co. v. R. R. Commission, 27I U. S. 583, 593 (I926). "Having regard to form alone, the act here is an offer to the private carrier of a privilege which the state may grant or deny, upon a condition, which the carrier is free to accept or reject. In reality, the carrier is given no choice, except a choice between the rock and the whirlpool,- an option to forego a privilege which may be vital to its livelihood or submit to a requirement which may constitute an intolerable burden." 
crisis as an instrument of coercion, the entire purport of the doctrine of "unconstitutional conditions", as stated by the court, establishes that an unconstitutional objective cannot be achieved through indirection by the exercise of means that are ordinarily constitutional. ${ }^{41}$

In the administration of the Lever (Food and Fuel Control) Act, ${ }^{42}$ the coercion was exercised not in individual negotiations, but in blanket fashion at the outset, since the groups affected were required to be licensed, the sanction employed being the subsequent revocation of that license. There is no doubt that a licensing scheme is an effective scheme of administration for centralizing control, in that the power to revoke or the threat to revoke the license can be used freely to enforce compliance. The courts were ready to give effect to the license provision by denying relief to an unlicensed dealer. In considering the practicability of extending license control to war-time industry, we should note that the effectiveness of the device in enlarging legal power is dubious indeed. The power to attach conditions to the grant of a license where the power to grant or deny that license is undisputed, is the vexatious issue confronting the courts in the field of "unconstitutional conditions". But it is an arbitrary assumption of power to attach conditions to a license where the power to deny that license does not exist $a b$ initio. Thus licensing, though a convenient administrative mechanism, does not avoid the problem of the legal basis of control. Rather, a decision to license is a four-square confrontation of the legal issue, since it is tantamount to a legislative declaration that the licensed groups had been subjected to regulatory control in the exercise of some Federal power.

In referring to cases in which the courts invalidated agreements under license as secured by duress, ${ }^{43}$ Baruch testified before the War Policies Commission that price control through "leadership" would never again be possible, and that broad statutory authority in direct terms would be necessary.

\section{The Solution by the Emergency Price Control Act}

The government must be able to purchase goods independently of market value; otherwise, the price paid by the government is tied as a tail to the spiralling kite of market value. This, however, could be done only by indirect means as long as the requisition concept was retained. The advance in constitutional doctrine in recent years per-

4I. Hale, Unconstitntional Conditions and Constitutional Rights (I935) 35 CoL. L. Rev. 32I ; Merrill, Unconstitutional Conditions (I929) 77 U. of PA. L. REv. 879.

42. 40 STAT. 276 (I9I7).

43. United States v. Smith, 39 F. (2d) 85 I (C. C. A. Ist, I930) ; United States v. Avery, 30 F. (2d) 728 (N. D. N. Y. I927); United States v. McFarland, I5 F. (2d) 823 (C. C. A. 4 th, 1926). 
mits a straightforward and direct solution-grounded on the principle of regulation. ${ }^{44}$ The present Price Control Act ${ }^{45}$ is based on a regulatory doctrine. The purpose stated in Section I (a), "to further the national defense and security," is in strict pursuance of a delegated Federal power. Offenders against price orders are subjected to penalties as in all regulations. The Government is empowered to secure an injunction where a violation has been committed or is about to be committed. This is a statutory injunction and no proof of irreparable injury or inadequate remedy by civil or criminal action need by shown. The Government can punish the commercial buyer, as well as the seller. Additionally, of course, the indirect sanctions used by OPA prior to the Act are in force. Non-commercial buyers may sue sellers for $\$ 50$ or treble damages; in all other cases the Government may bring a civil suit in its own behalf. ${ }^{46}$

Voluntary agreements are authorized by the Act. ${ }^{47}$ To be sure, violations of these agreements are not subject to the criminal penalties of the Act. OPA's present policy is to frame the formal agreement so that signers are subject to civil suits by injured parties under the third party beneficiary rule. In cases where voluntary agreements have been nullified by violations of signers, non-signing producers, or dealers engaging in speculative resales, OPA has been quick to supplant the agreement by a formal schedule.

As an implement to its enforcement powers OPA is authorized to license. ${ }^{48}$ It can issue a blanket license for all members of an industry, but it lacks the power to withhold the initial license from any member. Since a warning notice must be sent to the offender after the first violation, two violations are requisite for a revocation. The big stick of licensing was somewhat blunted by the decision of Congress that licenses should not be revocable by administrative action, but rather by court procedure. $^{49}$ However, the sole issue in such litigation is the fact of violation, not the validity or reasonableness of the price order.

From the start OPA has not limited itself to the price of goods bought by the government; the War Industries Board extended government prices to civilian purchasers only towards the end of its reign and then only after great debate. In this connection, an interesting constitutional question was brought out before the War Policies Commission. There are two divergent purposes to be served by price fix-

44. Hannah, Some Aspects of Price Control in War Time (I94I) 27 CoRN. L. Q. 2I, 47; Note, American Economic Mobilization (I942) 55 HARv. L. REV. $427,486$.

45. Pub. L. No. 42I, 77th Cong., 2d Sess. (Jan. 30, 1942).

46. Id., tit. I, § $4(\mathrm{a})$; tit. II, \$205(e).

47. Id., tit. I, \$ 5 .

48. Id., tit. II, $\$ 205$ (f) (I).

49. Id., tit. II, § 205 (f) (2). 
ing. One is to prevent profiteering at the government's expense and an increase in public expenditures; the other is to aid in the more effective conduct of the war by preventing economic dislocation and disruption of the morale. The effectuation of the latter aim may result, incidentally, in the effectuation of the former. However, the legitimate spring for action must be the more efficient conduct of the war, though this might be hampered by the inflation resulting from exorbitant expenditures.

It follows that the more drastic Baruch Plan is more readily sustainable on constitutional grounds than a piecemeal system of control, confined to commodities purchased by the government. In that case, it might be contended, and with some justification, that the government's object is not so much to regulate the price structure as, under the subterfuge of regulation, to diminish the amount of compensation it is obliged to pay under a taking.

\section{Regulatory Concept Applied to Civilian Purchases}

The power to fix prices, under the Lever Act was specifically granted as to wheat and fuel. Fuel has a dual use, in that it is a civilian necessary and is also required in large quantities by the government. The contrast in application between a regulation and a taking is here accentuated in a vivid fashion.

It is necessary to advert here to the method employed by the government in the last war in fixing prices for its purchases and which was applied also to the fixing of the price of fuel. The essence of price fixing was the bulk-line principle; ${ }^{50}$ the price of a standardized commodity was arbitrarily fixed at that price sufficient to cover the costs, plus a reasonable profit for the marginal competitor supplying the last unit of that proportion of the product necessary for the government's needs. Thus the low-cost producer received, in effect, a public subsidy measurable by the difference in efficiency between himself and the marginal competitor. On the other hand, the high cost producer above bulk-line was virtually driven from the industry, since he could not profitably fill a government contract, nor, since the price was made uniform for government and civilian purchases, could he compete in the civilian market.

In the present-day operations of OPA, definitive prices are not set in two fact situations. In one case the administrator promulgates a temporary price regulation which under the act is effective for only

50. For a description of bulk-line procedure, see Taussig, Price Fixing as Seen by a Price Fixer (I9I9) 33 Q. J. ECON. 205, and HARDY, WARTMME CONTROL OF PRICES (1940) 62 . 
sixty days and must be based on prices prevailing five days prior to the issuance of the order. ${ }^{51}$ OPA employs this medium in cases where action is imperative, but an industry study has not been completed. In the second case OPA finds it impossible to prescribe uniform prices because of the diversity of markets or geographical areas or because no markets exist. In these two situations the practice has been to set the price for each individual on the basis of the price charged by him to the same class of purchaser during a specific period. However, where prices can be fixed, bulk-line is as applicable today as it was in the last war. Of course, the term "bulk-line" is not used today, nor does the determination of price assume to the same scientific precision which bulk-line claimed. Prices are set more or less on the basis of expediency; but cost is the most important factor in the decision. Prior to the issuance of a schedule or regulation, exhaustive questionnaires are sent to all members of the industry inquiring as to costs of operation. The price, as in bulk-line, generally covers about 80 to 90 per cent. of the members of an industry on the basis of costs. The remaining Io to 20 per cent. must apply for exemption under the "hardship and inequity" clause contained in regulations, and exceptions are denied where the production is proven to be for only civilian use. Thus the net effect of the procedure today is that bulk-line still prevails, and this conclusion is not altered by the fact that the recent statute exhorts the Administrator to give due consideration to prices as between October I and I5, I94I, with adjustments for increases and decreases in production, distribution, and transportation costs.

Baruch, in his I92I Report, conceded that the Board, in applying bulk-line, had been advised by their lawyers that the touchstone of value in a taking would be market value but stated that since, according to classical economic theory, market value tends to gravitate toward cost, in the abnormal war economy it was justifiable to base value on costs. The bulk-line approach was submitted to judicial test, however, in the cases under the Lever Act.

In Morrisdale Coal Co. v. United States ${ }^{52}$ the petitioner had orders for the sale of large amounts of coal above that fixed by the Fuel Administrator. In consequence of sales at the fixed price, he lost the opportunity to make a large profit. In a suit against the government for the difference, or "just compensation", Mr. Justice Holmes said:

"We see no ground for the claim. The claimant in consequence of the regulation mentioned sold some of its coal to other parties at less than what otherwise it would have got. That is all.

5I. Pub. I. No. 421, 77th Cong., 2d Sess. (Jan. 30, 1942) tit. I, \$ 2 (a).

52. 259 U. S. I88 (1922). 
It now seeks to hold the government answerable for making a rule that it saw fit to obey. Whether the rule was valid or void no such consequence follows. Making the rule was not a taking and no lawmaking power promises by implication to make good losses that may be incurred by obedience to its commands. If the law requires a party to give up property to a third person without adequate compensation the remedy is, if necessary, to refuse to obey it, not to sue the lawmaker." 53

On facts similar to those of the Morrisdale case, in Pine Hill Co. v. United States, Mr. Justice Holmes said: ${ }^{54}$

"A liability in any case is not to be imposed upon a government without clear words. But liability for a regulation, for the consequences of a law, on the part of the legislative power, is most unusual, and where, as here, the liability would mount to great sums, only the plainest language would warrant a Court in taking it to be implied."

These decisions are unique in their outright recognition of the regulatory nature of price fixing. Three considerations impelled the decisions. (I) The law is obviously based on the exercise of a delegated Federal power, the war power, rather than on the inherent power of eminent domain; (2) the government is not enriched by dealings between civilians, and hence no implied contract to reimburse can be spelled out; (3) the owner is not compelled to sell, and hence the unilateral compulsion of eminent domain is lacking. E. N. Griswold and Thomas D. Thacher in briefs submitted to the War Policies Commission stated that the fixing of: all prices, even in civilian transactions would be subject to the constitutional right of review by the courts as to just compensation; these opinions ignore the plain import of Holmes' decisions.

In Highland $v$. Russell Car Co. ${ }^{55}$ a coal owner contracted to sell coal at a higher price than that fixed under the Lever Act. He sued for the difference, alleging that Congress had no power to fix prices without providing just compensation for those who, in the absence of such regulation, might have sold their product for more. In denying recovery Mr. Justice Butler traced the history of the legislation and asserted that as a measure enacted in the due exercise of the war power there was a strong presumption of validity to sustain it. He went on to say, however, that the principal purpose of the Lever Act was to enable the government to acquire fuel at reasonable prices. "Plaintiff was free to keep his coal, but it would have been liable to seizure by

53. Id. at Igo.

54. 259 U. S. I9I, I96 (1922).

55. 279 U. S. 253 (I929); Davis v. Newton Coal Co., 267 U. S. 292 (I925); E. I. DuPont de Nemours \& Co. v. Hughes, 50 F. (2d) 82 I (C. C. A. 3d, I93I), semble. 
the government." 56 In that case, Mr. Justice Butler said, it did not appear that plaintiff would have been entitled to more.

In pointing out that "the plaintiff was free to keep his coal", $\mathrm{Mr}$. Justice Butler was extending the analysis of the validity of price fixing as a regulation under the war power. In the same vein, he might have adverted to the Morrisdale and Pine Hill cases to corroborate the point that if the duty attaches to render just compensation, a suit against the government would be successful. However, Mr. Justice Butler's assertion that the property if requisitioned would be worth no more, and his statement that the primary intent of the Lever Act was to supply the government with the commodities at reasonable prices are unfounded. On the contrary, where the property is requisitioned a different judicial approach is adopted.

That the hallowed measure of compensation in a "taking" is market value was reiterated in several war-time requisition cases. ${ }^{57}$ However, the rule becomes difficult of application where a free market price has become a fixed market price. Under such circumstances, the government should be liable for no more than the owner would have been able to obtain in the absence of a requisition, namely, the price in the fixed market. Judicial reasoning, deeply ingrained with the habit of basing value on market price in condemnation, has balked at adopting a course which Attorney-General Mitchell adduced as a reductio ad absurdum arising from the separation of the two powers.

"If Congress has the power to provide for fixing prices generally in private transactions, it could then establish a market price which may be persuasive or controlling in determining just compensation where the government takes property for public use, and so through the exercise of one sovereign power, that of establishing prices under the war power may thus indirectly affect or control the price it must pay when exercising the power of eminent domain." 58

In the New River Collieries Co. ${ }^{59}$ case, since the prevailing domestic price of coal was the one fixed by the government, the Supreme Court upheld the exclusion of evidence as to that price. Moreover, evidence as to the owners' cost of production plus a reasonable profit, the bulk-line method, was also held rightly excluded. The Court, however, managed to find an export market for coal, and rendered just

56. 279 U. S. 253,262 (1929).

57. Phelps v. Unnited States, 274 U. S. 34I (1927) ; United States v. New River Collieries, 262 U. S. 34I (1923); Seaboard R. R. Co. v. United States, 26I U. S. 299 (I923).

58. Hearings Before Honse Military Affairs Committee on $H . R .3$ and $H . R$. 5293, 74th Cong., ist Sess. (1935) 735.

59. 262 U. S. 34 I (I923). 
compensation on the basis of "spot prices" there prevailing. The result was that the government was forced to pay $\$ 20$ a ton for coal which had cost $\$ 5$ a ton.

The Court's decision is vulnerable on several grounds: (I) "spot market" prices for coal are notoriously in excess of prevailing contract prices; (2) whether the plaintiff would have sold in that market is purely hypothetical; (3) if all owners sold their coal there, the high price there prevailing would not exist; (4) the validity of the export market price as unaffected by the domestic situation is extremely dubious; (5) it was against public policy to sell in the export market. The plaintiff could have done many other things with his coal contrary to public policy, such as speculating and hoarding.

Paradoxically, however, a situation may arise in which no market can be discovered other than the one functioning under government control. That is, the price may be fixed effectively in all markets, as OPA hopes to accomplish today. In L. Vogelstein \& Co.v. United States, ${ }^{60}$ the government was sued for the market price of copper taken, allegedly, under compulsory order. No market was available other than the one in which the price fixed by the War Industries Board prevailed. The Court, therefore, declared that fixed price constituted the market price. It is thus evident that even a palpably illegal attempt to stabilize the price structure for government purchases would serve a useful purpose in that, though the government were compelled to pay full compensation after the war, the prices for its purchases would be kept under control. More than that, such compensation might not be forthcoming on suit, if no free market could be found, as the Vogelstein case demonstrates.

The courts seem to have been oblivious to the complete futility of an attempt to accommodate conventional legal principles to an organically different economy. ${ }^{61}$ Price, as the great regulator of the market. and the flow of resources, could not be entrusted to the workings of the ordinary laws of supply and demand. The rules of the peace-time competitive economy had to be adjourned, since the extraordinary government demand, unabated by any rise in price, exceeding available supply, would cause prices to skyrocket. To eliminate the demand attributable to ordinary civilian needs, priorities were instituted; to

60.262 U. S. 337 (1923). There were decisions by state courts to the same effect. Wis. \& Ark. Lumber Co. v. Buschow Lumber Co., 257 S. W. 840 (Mo. App. 1924);
Clements v. Cook, II2 Wash. 217, I9I Pac. 874 (I920).

6I. C. G. Blake Co. v. United States, 275 Fed. 86i (S. D. Ohio, rg2I). See National City Bank of New York v. United States, 275 Fed. 855, 860 (S. D. N. Y. I92I). "The government, as a war measure under the exercise of governmental powers, may fix prices, either directly or by governmental regulations necessarily reducing the prices; but this does not authorize it to acquire the property in invitum at such reduced prices." Prince Line v. United States, 283 Fed. 535, 540 (E. D. N. Y. I922). 
further eliminate the influence of the segment of civilian demand, price fixing was introduced, based not on market value but on costs.

It therefore appears that the theoretical free market price which the courts assign for just compensation is precisely that skyrocketing price which the government seeks to avoid paying. Any other market price is sham and illusory.

We have noted that the courts adopted the regulatory theory in the case of price fixing between civilians. To compartmentalize the different aspects of control, to regard the government's relationship with industry as a government taking and the regulation of civilian business as in a different category, is to apply traditional judicial dogma in a fictitious world. Actually, a coherent unity or merger subsists between the two spheres. The following points illustrate this unity. (I) The government and civilians buy in the same market. (2) The War Industries Board found that it was essential to extend the government price to civilians. (3) The bulk-line cost method was applied in both. fields, fuel being fixed in price in that manner. Both price frameworks are intimately intertwined in the problems of the overall price structure, since the latter is determined collectively by all prices paid, regardless of the public or private capacity of the buyer. (5) It is impossible to stabilize the prices of industrial commodities unless basic component costs are stabilized.

The simplified approach to the problem is to view the fixing of the price between industry and the government as part of the integrated whole of regulation, rather than as an isolated event requiring just compensation, the amount of which the government may be able to control in fact by its control of the private markets, or even by the use of extralegal methods, as we noted in the Vogelstein case. If the price to be paid is the fixed price prevailing in the entire market, then the government is merely another customer, endowed, however, with certain prerogatives of direct action to fill its needs. From an objective viewpoint, the sale to a private customer and the sale to the government have the same effect on the balance sheet of an industry. From the standpoint of the government, it has eliminated a large segment of the civilian demand, and in an entrepreneurial capacity has put itself in the shoes of the former customer. Thus, to favor a particular seller with a higher price because a free market may somehow, somewhere, be unearthed is a thoroughly indefensible procedure.

In the event that the price is fixed in the civilian markets, it seems desirable that the duty to supply the government with the finished product at the same price be stipulated as a regulation. The duty to deal with the government is no more burdensome than the regulations 
as to the price at which the commodity can exchange. Both should be integrated in the same sovereign command. This, the present act fails to do.

It is certain that the just compensation concept is not obliterated under the impact of the war power. According to Mr. Justice Hughes's interpretation of Ex parte Milligan ${ }^{62}$ as rendered in the Blaisdell case, ${ }^{63}$ in times of emergency a constitutional power may be expanded by judicial exposition in a case where the provision is set forth in merely general terms. Thus, the due process clause, lacking any specific definition, may in time of war become attenuated almost to the point of final extinction. However, the just compensation clause does not admit of pliable construction and a taking with anything less than just compensation would be a direct denial of the constitutional mandate. The failure of the present Act to encompass dealings of private individuals with the government within the regulatory framework, as applied to dealings between civilians, gives rise to serious questions. Compulsory orders under Section 9 of the Burke-Wadsworth Act are placed with great frequency. In view of past judicial action, what will be the attitude of the courts if a claimant protests against the use of a fixed price in an eminent domain proceeding?

The problem arises more acutely in another context. Under the recent Property Requisitioning Act ${ }^{64}$ the commandeering is totally disassociated from the fixing of prices. In the latter part of February the War Production Board requested holders of aluminum stocks to make them available to the Metals Reserve Corporation at prices as much as 50 per cent. below market value, the lowered prices being justified on the ground that a substantial portion of the aluminum would have to be remelted. The government threatened to use its requisition power in case of non-compliance. Can a holder of aluminum in such a case get full market value in a requisition proceeding, rather than the reduced government price?

\section{Scope of Review under Emergency Price Control Act}

Under the recent Act hearings are not essential, since the action is quasi-legislative rather than quasi-administrative, affecting classes of persons rather than individuals. But Congress has enjoined the Administrator, as far as practicable, to advise and consult with representative members of the industry affected. ${ }^{65}$ OPA Regulations No.

62. 4 Wall. 2 , I20 (U. S. I866).

63. Home Building \& Loan Association v. Blaisdell, 290 U. S. 398, 425-426 (1934). See United States v. I. Cohen Grocery Co., 255 U. S. 81, 88 (1920) rejecting the viewpoint of Wambaugh, War Emergency Legislation-A General View (I9I7) 30 HARV. L. REV. 663, that the Constitution does not operate in war-time.

64. Pub. L. No. 274, 77th Cong., Ist Sess. (Oct. I6, I94I).

65. Pub. L. No. 42I, 77th Cong., 2d Sess. (Jan. 30, I942) tit. I, § 2(a). 
I, recently issued, state that formal hearings will be entirely optional with the Administrator. However, consultations with industrial advisory committees and representatives help OPA to avoid arbitrary action, which would give rise to numerous actions for review.

After the issuance of an order, a formal procedure is established for protest to OPA and for subsequent review by the Emergency Court of Appeals. ${ }^{6 B}$ If a person is not subject directly to the order, he can only file a petition for amendment under OPA Regulations No. I. If the schedule can be altered to fit his particular case, an affected person can file a petition for an exception, and upon denial a protest can be made.

Upon what basis can such a protest be grounded? If price control is properly viewed as a regulation rather than as a requisition, then it is futile to appeal on the ground that a just compensation for the product is not fixed or that a schedule does not allow a "fair return on fair value" on his business as a whole. On the other hand, as the General Counsel of OPA stated in the hearings before the House Committee, the standard of review laid down by the Act, "arbitrary and capricious", is broader than the usual "substantial-relation" rule adopted in administrative proceedings. Thus in addition to the customary ground for review, an affected person may appeal on the following grounds:

$x$. That the order is arbitrary in that the rate set is confiscatory for most of the members of the industry (see Hegeman $v$. Baldzin).

2. That the order is arbitrary in that the statement of considerations as affixed to the price order under the mandate of the law is at variance with the actual provisions of the order.

3. That the order is arbitrary in that OPA proceeded without ascertaining proper economic data or that the data as submitted by industry members was ignored.

4. That the order is arbitrary in that no differentiation or discrimination is made between different grades of goods or different members of the industry.

5. That the order is arbitrary in that it is unintelligently or unreasonably drawn as that a higher price is set for a lower grade of goods.

Additionally, the Act provides that a protest and an appeal can be made on the ground that the order is illegal. This could best apply in cases where the price order ignores standards as to farm products and goods processed from them, or where the Administrator failed to give

66. Id., tit. II, $\$ 204$. 
due consideration to the October I-I 5 level of prices, or where, in contravention of the statute, the order altered the normal trade practice of an industry.

\section{"A FAtr RETURn on FaIr Value" for War Industrtes}

The retention of the requisition is tenable only as to its modified form- "fair return on fair value" of the going concern. Applicable to the product itself, compensation is measurable by the price prior to alteration, thus nullifying the adventure in price fixing.

The occasion for the employment of the concept is unnecessary in the exertion of the war power, but is cognate to the "affectation with the public interest" doctrine. Under a broad-gauged view of the essential nature of the doctrine, it presents itself as an excellent medium for the projection of the controls of price fixing and priorities. To what extent do war-time industries partake of the nature of public utilities? The problem may be viewed in its multi-dimensional aspects thus:

( I) From the standpoint of the public exigency, a business which ordinarily is exempt from public control may hold such an immediate relationship to the public need as to require regulation. The intimate relationship of war-time industry with the effectuation of the public welfare during armament is clearly in this category.

(2) Due to the inelasticity of supply in relation to demand, the "regulative force of competition" in controlling price has been suspended. Thus the public is justified, as in the case of public utilities, in setting a price which would prevail theoretically in the presence of competition.

(3) The features characteristic of public utilities are conspicuous in the heavy goods, war-time industries. The essentiality of the service is undisputed. Due to the physical limitations of expansion, a practical monopoly is enjoyed. They are endowed with monopolistic privileges akin to utilities, that is, priorities. Most of these industries operate under heavy overhead costs and decreasing unit costs. The government, as a large consumer in place of the public, with steady industrial demand on "peak" production seeks to lower the charges it must pay.

It is impossible to calculate just compensation on the basis of the bulk-line system since it postulates a uniform unit cost independent of volume of production. A fair return on total operation will depend on getting a sufficient volume of business, unless it be assumed that marginal costs of production are uniform regardless of volume of output.

The bulk-line approach (or its equivalent) enhances the return to the efficiently conducted utility due to the large differential. Since 
average cost shrinks with optimum rate of production, profit rate increases. Moreover, as the British experience in World War I demonstrated, there are certain real savings incident to war-time production, arising from the lack of competition and the steadiness or predictability of demand. ${ }^{07}$

The plain legal import of the public utility doctrine encourages an effort to prevent distorted profits by devices calculated to limit wartime profits to a "fair return on fair value". There are three devices that are to be considered.

The first, and the obvious one, is the subsidization of high-cost producers who are responsible for a small volume of the output rather than to permit that minor output to influence the price. This has been applied recently by OPA in regard to copper, lead, and zinc in accordance with Section 2 (e) of the Act, authorizing government purchases from high-cost producers. Under this modification of bulk-line, quotas were set for individual mines and over-quota production was rewarded by specific premiums. The second method, tried successfully in the boot industry by Britain during the last war, is to group together manufacturers with roughly uniform costs. The third, and most controversial due to heavy administrative difficulties, is the "equalization pool" device. ${ }^{68}$ This was strenuously urged before the War Industries Board in the last war, and Britain is carrying on experiments in this direction at the present time.

A recapture provision for excess profits appears to be the logical solution, but if the total profits are received in the first instance by the industry subject to subsequent recapture, a repetition of the debacle under the Transportation Act of 1920 is inevitable. If, instead of bulk-line, the price were set at average cost plus a reasonable profit, an equalization pool might be established to transfuse excess profits from low-cost to high-cost producers. Each member would receive initially his standard pre-emergency return. The burden would then be cast upon each to offer proof of the difference, if any, between such return and a "fair return on fair value", wherein an opportunty would be afforded to show increased operational costs attributable to the heavy government demand. To preserve the advantages of the incentive to efficiency, a sliding-scale scheme might be combined, as a moderate reward to low-cost production.

Such a plan has the practical advantage over the excess profits $\operatorname{tax}$ as a device to reduce profits, in that it combines that objective with drastic lowering of price and control over the price structure.

67. Lloyd, Experimínts in State Control (I924) 320, 321.

68. For the constitutionality of the "equalization pool" device, see United States v. Rock Royal Co-operative, Inc., 307 U. S. 533, 570 (r939). 